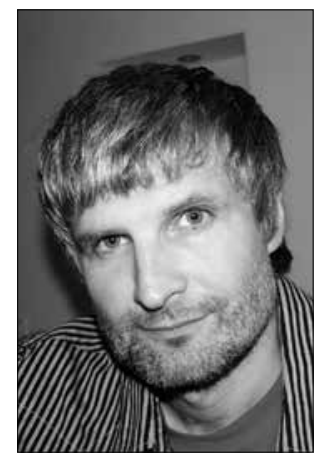

\title{
NUO GYDANČIO MENO IKI DAILĖS TERAPIJOS - TARPDALYKINIŲ TYRIMŲ PERSPEKTYVA
}

\author{
From Healing Art to Art Therapy: \\ Interdisciplinary Research Perspective
}

\begin{abstract}
SUMMARY
The review discusses the ideological content of the collective monograph Art, Therapy, Health (2017). It highlights the ideas formulated by all of the co-authors, including their conceptual descriptions. The wording of the article is responsive to its aim and evolves on two intertwining levels. On the one hand, the ideas researched by every single co-author, including their context and related assumptions are briefly discussed in the text. On the other hand, the article highlights certain general connections between the contexts to which different authors subject their research. The texts that are discussed in the article represent a reflexion on both art therapy as such and related research in the neighboring fields. This definition of the field of research emphasizes the interdisciplinary nature of art therapy as part of the texts represent the humanitarian disciplines that research visual culture and artistic expression. Another part of the texts is a clear representation of such fields as medical science and related applied research. The array of problems subjected to research is extremely wide. It ranges from intercultural assumptions on the proximity of therapeutic endeavors and artistic expression and goes on to topical research in the field of art therapy. Finally, the array shows the variety and efficiency of methods selected for application.
\end{abstract}

\section{SANTRAUKA}

Apžvalgoje aptartas kolektyvinės monografijos Menas, terapija, sveikata (2017) idèjinis turinys išskiriant bei konceptualiai apibūdinant kiekvieno autoriaus plètojamas idejjas. Straipsnio tikslą atitinkantis dèstymas tarsi padalintas i du supintus lygius: viena vertus, glaustai įvardytos kiekvieno autoriaus tiriamos idejjos / ju kontekstas, suformuluotos prielaidos, kuriomis remiantis tos idèjos buvo pasitelktos; kita vertus, nužy- 
mėtos bendresnio tipo sąsajos, susiejančios skirtingų autorių tiriamus kontekstus. Aptariami tekstai atspindi tiek dailès terapijos, tiek su ja siejamus gretutinių sričių tyrimus. Taip nužymėtas tyrimų laukas pabrėžia tarpdalykinį dailès terapijos pobūdi - dalis tekstų atstovauja humanitarinėms, vizualinę kultūrą ir meninę saviraišką tiriančioms disciplinoms, kita dalis - medicinos mokslams ir ju grindžiamiems taikomojo pobūdžio tyrimams. Pristatomas probleminis laukas itin platus: nuo bendrakultūrinių terapinès pastangos ir meninès saviraiškos suartejjimo prielaidų iki aktualių dailès terapijos tyrimų, demonstruojančių pasirinktų metodų taikymo įvairovę bei efektyvumą klinikinès medicinos aplinkoje.

$\mathrm{D}$ ailès terapijos metodai Lietuvoje taikomi - ivvairiais profesionalumo lygiais - jau keletą dešimtmečiu ${ }^{1}$, tačiau visapusiškai ruošti šios srities specialistus jungtineje magistro studiju programoje pradèta tik prieš penkmeti. Dèl suprantamų priežasčių mūsų šalyje nèra ilgalaikès dailès terapijos tyrimų tradicijos ${ }^{2}$, todèl naujos profesijos inicijuotą tyrimu bangą galima vadinti tokios tradicijos įžanga ar kokybiškai nauju etapu. Natūralu, kad didelè dalis dailès terapijos tyrimu Lietuvoje vykdomi pirmą kartą ir sietini su minèta magistro studiju programa.

Galima būtų vardinti sunkumus, kuriuos per paskutinius kelis dešimtmečius turëjo iqveikti naujosios profesijos entuziastai propaguodami savo profesiją. Kita vertus, tai natūralios problemos inicijuojant bet kurią naują terapinę disciplina, ir nederètu ju pervertinti ${ }^{3}$. Nepalyginamai akivaizdesnè pozityvioji poslinkiu pusè. Per gana trumpą laiką atsirado profesijos pirmeiviai, būtinas kompetencijas igiję savarankiškai ir padedami užsienio specialistų, îsikūrè ir sẻkmingai funkcionuoja visuomeninès organizacijos ${ }^{4}$, buriančios meno ar dailès terapijos metodus taikančius specialistus. Svarbiausia, sėkmingai veikia naujos srities profesionalus ruošianti programa, vienijanti Lietuvos sveikatos mokslų universiteto ir Vilniaus dailès akademijos
Kauno fakulteto specialistu pastangas. Taip pat inicijuotos nauju meno terapijos specialybiu studijos kitose Lietuvos aukštosiose mokyklose. Šiuo požiūriu mūsų studiju programų pozicijos nuteikia optimistiškai: mes ne tik stojome i vieną gretą su šalimis, turinčiomis gilesnes dailes terapijos taikymo tradicijas, bet ir lenkiame daugeli Europos šalių, pripažistančiu dailès terapiją tik atskiru metodu pavidalu.

Dailès terapijos terminas rašytiniame lietuviakalbiame diskurse paprastai siejamas su pasirinktu metodu specifikos aiškinimais, ju taikymo aprašais, gautu rezultatu aptarimais. Tokiu, siauros disciplinos rẻmų neperžengiančiu pavidalu, dailès terapiją Lietuvoje pristato ne viena publikacija, tiek verstiné ${ }^{5}$, tiek ir lietuvių autorių ${ }^{6}$. Ši stereotipą peržengiančiu publikaciju ${ }^{7}$ nėra daug. Netrukus skaitytoją pasieksianti kolektyvinè monografija ${ }^{8}$ Menas terapija, sveikata vadintina bandymu išplèsti dailès terapiją grindžiančių ir inspiruojančių idèjų lauką. Todèl knyga skirta ne tik dailès terapijos idejju sklaidai ir populiarinimui, bet ir kitu, su dailès terapija siejamų kultūros laukų tyrimams. Knygos struktūra atspindi tarpdalykini dailès terapijos pobūdị: dalis autoriu atstovauja humanitarinėms, vizualinę kultūrą ir meninę saviraišką tiriančioms disciplinoms, kita dalis - medicinos mokslams ir ju grin- 
džiamiems taikomojo pobūdžio tyrimams. Aptariamas probleminis laukas itin platus: nuo bendrakultūrinių terapinès pastangos ir meninès saviraiškos suartẻjimo prielaidų iki aktualių dailès terapijos tyrimu, demonstruojančiu pasirinktų metodų taikymo įvairovę bei efektyvumą.

Rašant kritinę minètos monografijos apžvalgą ${ }^{9}$ buvo remtasi prielaida, kad konkrečius straipsnius grindžiančios perspektyvos atstovauja vienai, humani- tarinei ar medicininei, mokslo sričiai, tačiau jų derinys monografijoje kuria tam tikrą šiu sričiu sąveika, generuodamas bendrą tarpdalykinių tyrimų lauką. Todèl straipsnio tikslas tarsi skilo ị du susijusius lygius: viena vertus, konceptualiai ivardytos kiekvieno autoriaus tiriamos idejjos/ju kontekstas, išskirtos prielaidos, kuriomis remiantis tos idejjos buvo analizuotos; kita vertus, glaustai nužymètos bendresnio tipo sąsajos, jungiančios skirtingu autorių tiriamus kontekstus.
Pirmame knygos skyriuje pristatomos Vakarų humanistikoje ir dabartinės kultūros tyrimuose išsikristalizavusios idejjos, ¿vairiais aspektais sietinos su dailès terapijos diskursu. Išskiriami ir konceptualizuojami istoriniai idèju raidos ir paradigminių pokyčiu momentai, paruošę dirvą psichoterapiniu perspektyvų i̇sigalejimui (A. Andrijauskas, S. Mostauskis), taip pat aptariami dabartiniai vizualios kultūros studiju (O. Žukauskienè) ir su psichopatologijos fenomenu siejamų komunikacinių problemu (K. Šapoka) kontekstai.

Antano Andrijausko straipsnis skirtas XIX-XX a. Vakaru humanistikoje populiariems išskirtinio meninio talento ir psichinès patologijos santykiams aptarti. Dèl apimties ir kone enciklopedinès temos atsklaidos straipsnis neabejotinai vadintinas mokslo studija. Pasitelkus skirtingas tarpdalykines prieigas įvairiapusiškai analizuojami psichopatologiniai menininko asmenybès, jo kūrybinio potencialo ir meninès kūrybos proceso aspektai. Andrijauskas pritaria jo tyrimu lauką grindžiančiai prielaidai apie psichinių deviacijų ir išskirtinių meninių galiu koreliaciją. Jungdamas pasirinktų mokslininku propaguojamas nuostatas, mokslininkas braižo savotišką idejju ir metodiniu perspektyvų žemèlapi, atliepiantį tuometi psichopatologijos ir meninès kūrybos santykių diskursą bei jo kaitą. Remdamasis chronologine idëjų genezès logika, grupuoja požiūrius, aiškinančius psichikos deviaciju poveikį menininko pasaulëjautai, estetinèms nuostatoms, kūrybinès veiklos rezultatams ir pan. Tai ne medicininiai patografiniai gyvenimo istorijų tyrimai, bet juos saistančių metodinių perspektyvų bei idejiniu prielaidu apžvalga, dèstoma pirmiausia iš meno filosofijos ir meno psichologijos perspektyvų. Dailès terapijos diskursas straipsnyje tiesiogiai neaptariamas, tačiau atidus skaitytojas netruks pastebėti, kad psichopatologijos ir meninès saviraiškos sankirtu tyrimai neabejotinai inspiravo vèlesnį dailès terapijos idejjų lauką.

Stasio Mostauskio straipsnyje siekiama apibrèžti paradigmines vakarietiškos sąmonès slinktis ${ }^{10}$, sukūrusias prielaidas dailès terapijai atsirasti. Remiamasi prielaida, kad šie pokyčiai menines ir tera- 
pines pastangas susiejo iš esmès nauju santykiu: pasitelkdama meninę saviraiš$\mathrm{ka}$, medicina igijo teisę interpretuoti ir koreguoti individo vidujybę. Straipsnyje aptariama: a) antropologinių sampratu slinktis, išplètusi ir supriešinusi žmogiškos prigimties teritorijas ${ }^{11}$; b) psichiniu ligonių "išradimas", kai žmogaus nebūti bepročio pavidalu pakeite psichine liga sergančio žmogaus konceptas; c) kultūrinè psichinių ligonių saviraiškos emancipacija, suteikusi ju kūrybai prasmingos komunikacijos formą; d) nauja autorystès koncepcija ir autoriaus tapatumo kūriniui idèja, subrandinusi kūrybos kaip saviraiškos sampratą; e) meninès saviraiškos virsmas būtina terapinio efekto sąlyga, suteikiančia galimybę savižinai virsti savigyda.

Odetos Žukauskienès refleksijos tiesiogiai nenukreiptos i dailes terapijos idejų lauką ar tų idèjų taikymo ypatumus. Ją domina išskirtines galias igavusi vizualine kultūra ir jos poveikis individui, taip pat to poveikio generuojamos grèsmès, neretai sietinos su patologiniais efektais. Autorès nuomone, šiuolaikinis vizualinis kontekstas pasižymi itin įvairialypiu ir ambivalentišku poveikiu. Viena vertus, jis neakivaizdžiai patologizuoja vizualinès kultūros vartotoju mąstysena, iškreipia gebejjimą atsiriboti ir kritiškai reflektuoti tokio poveikio pasekmes. Kita vertus, patologijos fenomeną paverčia savo dèmesio objektu ir aktyviai socializuoja. Kitaip tariant, vizualioji kultūra funkcionuoja dviem vienas kitą palaikančiais ir tuo pat metu neigiančiais režimais: a) iškreipia / patologizuoja vartotojo sąmonès ir vaizduotés procesus, b) išskiria ir estetizuoja pato- loginius reiškinius, teikdama jiems socialiai priimtinas tapatybes. Autorè remiasi prielaida, kad būtent masinè vizualinè kultūra, pirmiausia kinas, suteikè galimybę kone pasinerti i psichikos problemų turinčiu individų išgyvenimus, paverčiant juos pozityviai atpažistama ir priimtina bendražmogiškos patirties dalimi. Tai neabejotinai stiprus socializuojantis impulsas, mažinantis tokių individų socialinę atskirtị bei kitus stigmos efektus.

Autorès aptariamos vizualinės struktūros toli peržengia dailès terapijos palaikomas neverbalinès komunikacijos ir simptomų ekrano funkcijas. Tai bet kurių vizualiai aptinkamu formu prigimties, poveikio ir atsklaidos tyrimai suvešejusio vizualumo kontekstuose. Pasitelkta vaizdo antropologijos perspektyva traktuojama kaip psichoanalitinių disciplinu alternatyva, pabrèžianti išorinio konteksto poveiki individui. Kalbama ne apie vidujybès atverti, neabejotinai esminę dailès terapijai, bet apie tos vidujybès priklausomybę nuo išorinio konteksto, apie vizualios išorybès transformacijas ir funkcionalumą vidujybès erdvëje.

Kęstučio Šapokos nuomone, nūdienos psichoterapijos baruose vyksta slinktis nuo „giluminių" prie tarpasmeninių psichikos reiškinių tyrimu, pabrèžiant ne individualios sąmonès lygiu sąsajas, bet tarpasmeninès sąveikos situacijas ir jas iremminantį socialinį kontekstą. Pastarojo ir psichopatologijos reiškinių sandūrose kylančias komunikacines problemas autorius interpretuoja remdamasis keliomis pamatinemis prielaidomis: a) bet koks bandymas pasitraukti iš visiems iprasto komunikacinio lauko nerealizuotinas iš 
principo - individuali komunikacijos stoka, vengimas ir pan. yra kita komunikacijos forma; b) net hermetiškiausia individualios vidujybės struktūra iš principo nèra hermetiška; c) jos siunčiamas pranešimas traktuojamas kaip informacinè apykaita, o ne statiškas ir nepriklausomas prasminis vienetas; d) nėra absurdiškos ar beprasmės komunikacijos - yra tik žinomi ar nežinomi informaciniai kodai; e) net enigmatiškiausias informacinis kodas funkcionuoja reikalaudamas atskleisties. Šios prielaidos atspindi psichopatologijos generuojamų prasmių ir su ja siejamų komunikacijos sampratų slinkti, siekiančią išvaduoti psichinio ligonio tapatybę ir socialinius vaidmenis nuo represinès „juodos dèžès“ koncepcijos, dominavusios klasikinèje psichoanalizèje ir modernioje psichiatrijoje. Autoriaus nuomone, šiuolaikinëje Vakaru visuomenëje pastebimas polinkis integruoti ir kartu redukuoti psichopatologijos reiškinius į atpažįstamas ir priimtinas socioestetines formas, kitaip tariant, suteikti patologijos fenomenui komunikatyvią galią. Tokius procesus autorius sieja su metafiziniu problemu redukcija ir jos inspiruotomis slinktimis funkcionalizmo bei pragmatizmo link. Būtent šias slinktis, Šapokos teigimu, atspindi dailès terapijos idejos, transformuojančios metafizinius filosofijos aspektus i spekuliatyvios retorikos tariamai atsisakiusias praktikas.
Antrame skyriuje aptariamos pasirinktos meninès perspektyvos ir jų sankirtos su dailès terapijos idejomis. Nagrinëjami materialios aplinkos ir konkrečių daiktų inspiruoti santykiai su individu, siekiant šia kryptimi plèsti dailès terapijos akirati (M. Hills), analizuojamos socialiai angažuoto meno taikymo galimybès sveikatinimo įstaigose (J. Varkulevičienè), aptariamas konkretus psichologinis spalvos suvokimo modelis bei ji grindžiančių pedagoginių metodų ypatumai (D. Katinaitè).

Margaret Hills straipsnyje analizuojamas ne dailès terapiją tiesiogiai palaikantis teorinis diskursas, bet bendresnio pobūdžio vizualinès ir materialinès aplinkos tyrimų laukas, sietinas su atminties studijomis ir atminties menais. Bandoma atsakyti i klausimą: kaip supantys daiktai ir ju inspiruojamos asociacijos lemia/palaiko konkretaus individo tapatybę? Gau- tus atsakymus autore siekia transformuoti i dailès terapeutams naudingą informaciją. Pavyzdžiui, galimybė komunikuoti per mus supančius daiktus ir ju generuojamas asociatyvias sankabas turi saugios neverbalinės raiškos požymių, itin svarbių dailès terapijos kontekste; o galimybè remtis daiktų skleidžiama atmintimi ir permąstyti save tos atminties akivaizdoje suteikia pagrindą teigiamiems savivokos pokyčiams. Kitaip tariant, tyrimas paremtas prielaida, jog tarpdalykinès socialinès antropologijos ir atminties studijos gali reikšmingai papildyti dailès terapijai iprastus klinikinius tyrimus ir jų siūlomas išvadas. Aptariamos pasirinktų autorių idejos, taip pat analizuojami meno projektai / kūriniai, autorès nuomone, dailès terapeutams suteikia vertingu ižvalgu ir leidžia plèsti terapinès veiklos akirati i žmogų supanti daiktų pasauli bei jo skleidžiamą atmintį. 
Jovitos Varkulevičienès straipsnyje keliami socialiai angažuoto meno ir meno terapijos santykių klausimai, neišvengiamai kylantys, kai meniniai projektai isiterpia į sveikatinimo įstaigu erdves, anksčiau rezervuotas tik specifinèms dailès terapijos praktikoms. Taip pat nagrinëjamos meniniu projektu taikymo galimybès sveikatinimo institucijose, mèginant suformuluoti tam tikras meno kaip užimtumo bei sveikatinimo funkcijas, tuo pat metu pabrěžiant jų menini, o ne medicininị pobūdị. Galu gale aptariamas atgalinis tokių intervencijų ryšys, stipriai veikiantis individualią menininkès/ straipsnio autorès poziciją bei kūrybines nuostatas. Autorès nuomone, socialinès meno praktikos sveikatinimo istaigose nèra tik terapinès strategijos ar metodinès priemonès, bet savo specifiniu autonominiu tikslu siekiantys sumanymai. Kita vertus, abieju sričiu veikimo principai bei metodai, nepaisant skirtingos prigimties, remiasi tarpdalykinèmis sąveikomis ir mainais, o daugiaprasmè meno paskirtis ir nauda sveikatinimo aplinkoje rodo, kad šiuolaikinio meno praktikos poveikio požiūriu suartèjo su terapiniais modeliais. Daroma išvada, kad šiuolaikinès vizualiųu menu ideologijos ne tik netelpa i tradicini priešpriešos terapijai modeli, bet neretai taip supanašeja, kad juos siejančių panašumų yra daugiau nei skirtumų.

Deimos Katinaitės straipsnyje dèmesys telkiamas i psichologinius J. Itteno koncepcijos aspektus, išskleidžiant daugiasluoksni spalvos suvokimo psichologinį modelį bei išryškinant svarbiausius jo pedagoginių metodų bruožus. Autorè aptaria ne specifines dailès terapijos, bet jai giminingos meno terapijos funkcijas, pirmiausia sietinas su psichologiniu spalvos poveikiu. Katinaites nuomone, saviraiška spalvomis Itteno koncepcijoje traktuojama kaip asmenybės augimas ir harmonizavimas atliekant menines užduotis, o kai kuriais atvejais ir kaip diagnostinis irankis: remdamasis pasirinktais kolorito deriniais, Ittenas nustatydavo mokinio psichologinę charakteristiką. Šio pedagogo nuomone, mūsu pareiga yra rasti visuotinai galiojančias spalvotyros taisykles ir išmokti jas taikyti psichinès bei fizinès asmens sveikatos stiprinimui.
Trečias knygos skyrius skirtas „tiesioginiams" dailès terapijos taikymo atvejams, didele dalimi siejamiems su klinikinès medicinos lauku. Čia pateikti Lietuvos ir užsienio mokslininkų tyrimus apibendrinantys darbai, pristatomos ivairialypès dailès terapijos taikymo metodikos. Aptariamos bendrosios dailès terapijos nuostatos, pabrèžiant fenomenologinius patirties ir refleksijos momentus (A. Brazauskaitè); kvestionuojami iprasti apibrèžimai, grindžiantys ankstyvosios kūno motorikos ir jos simbolizacijos aiškinimus (J. Dubowski); analizuojamas dailès terapijos efektyvumas padedant nuo vėžio besigydančioms (L. Lebedeva) ar valgymo sutrikimų turinčioms (V. Adomaitienè) pacientėms.

Kalbèdama apie dailès terapijos taikymo ypatumus, Audronė Brazauskaitė pabrèžia fenomenologinius - tiesioginès patirties ir jos refleksijos - momentus. 
Greta bendrų dailès terapijos funkciju aptarimo, autorè daug dèmesio skiria individualios terapinès patirties komentarams. „Konteinerio" terminu ${ }^{12}$ autorè apibrèžia subtilią pacientą ir terapeutą gaubiančią erdvę, atliekančią specifines sąveikos, atverties ir išteikties per meninę formą funkcijas. Būtent šioje erdvejje vidinè patirtis tampa išoriškai matoma tai pamatinis dailès terapijos ir meninès saviraiškos ypatumas. Autorès nuomone, vidujybès kalba yra intymi ir pažeidžiama, todèl esminè jos funkcionavimo sąlyga yra saugumas tiek išorinių dirgiklių, tiek vidinių negatyvių išgyvenimų atžvilgiu. Vidujybès žodžiai, kuriuos girdi tik kuriantysis, virsta formaliomis simbolinėmis struktūromis arba vizualumą igijusiais žodžiais. Ypač i̇domi straipsnio dalis, aprašanti mergaitès, vardu Sofija, atveji. Viena vertus, tai terapiniu seansu metu gautos informacijos dèstymas bei apmąstymas, pasirinktų terapinių metodų grindimas; kita vertus, tai jautrus, net intymus terapeutès ir pacientès santykių, ju bendros patirties atpasakojimas, virstantis kone savarankiška literatūrine istorija. Sofijos atvejo aprašas atskleidžia autorès kompetencijas vykdant individualizuotą kokybini tyrimą.

Kaip ir kiti dailès terapeutai, Liudmila Lebedeva remiasi prielaida, kad emocinę subjekto savijautą ir fizinę būklę sieja tiesioginis ryšys. Kitaip tariant, somatiškai išreikšta liga (šiuo atveju - pieno liaukų kancerogenezè) koreliuoja su ivairiomis emocinès deprivacijos formomis. Todèl pastarųu ų reguliavimas gali būti naudingas kovojant su tokiomis ligomis ar bent jų simptomatika. Autorès tyrimų tikslas: a) pasiūlyti dailès terapijos taikymo modeli, reguliuojanti patologines emocines būsenas, siejamas su ilgalaike pieno liaukų vėžio keliama įtampa; b) pagrissti tokio modelio terapinę naudą. Tyrimo rezultatai parodè, kad autorès siūlomas dailès terapijos modelis yra efektyvus psichologinès pagalbos teikimo būdas, stiprinantis psichoemocinę gyvenimo kokybę ir emocini onkologiniu ligonių atsparumą: po terapinių seansų pacienčių savivertè bei saugumo pojūtis sustiprèjo, padidèjo tikejjimas galimybe ivveikti ligą ir pan. Šis tyrimas reikšmingas ir kitu aspektu. Siekiant patvirtinti gautų rezultatų objektyvuma, buvo imti pacienčių kraujo mėginiai ir tirti objektyviai išreikšti neuroendokrininès sistemos pokyčiai. Psichoemocinę būklę ir neuroendokrininę sistemą sieja tiesioginè priklausomybè, todèl „objektyvių žymeklių" funkcijai atlikti buvo pasirinkti oksidantinio streso bei citokinų lygio rodmenys. Biocheminès analizès duomenys patvirtino teigiamus citokinu lygio pokyčius po dailès terapijos intervencijos.

Lebedevos tyrimas yra savotiškas atsakas "grynų" gamtamokslinių metodikų šalininkams, abejojantiems dailès terapijos efektyvumu arba tapatinantiems ji su trumpalaikiu "placebo efektu“. Ne tik subjektyvius išgyvenimus fiksuojantys instrumentai, bet ir laboratoriniai biocheminiai kraujo tyrimai, eliminuojantys žmogiško subjektyvumo veiksni, patvirtino dailès terapijos efektyvumą papildant kompleksini pieno liaukų vėžio gydymą.

Janeko Dubowskio straipsnyje siekiama atsakyti i esmini tyrimo klausimą: ar sunkia autizmo forma sergančio paciento, savo raida atitinkančio dar nekalban- 
čio vaiko etapa, sukurti piešiniai gali atspindèti sieki surasti „formą" savo psichologinei būčiai? Daroma prielaida, kad tokie ankstyvo etapo piešiniai yra nevaizduojamosios „reprezentacijos“ pavyzdžiai, kuriuose atsispindi ne regimo pasaulio formos, bet pamatinių suvokimo, atminties, gelminių impulsų atspindžiai. Tyrimo izžvalgos kvestionuoja iprastus apibrèžimus, siejamus su ankstyvosios kūno motorikos aiškinimu ir ja besireiškiančios simbolizacijos interpretavimu. Remiamasi nuostata, kad nepakanka tyrinèti baigtą piešinį; būtina studijuoti piešinio atsiradimą lemiančią elgseną ir realizacijos procesą. Autoriaus nuomone, paciento veiksmų seka piešiant gali būti laikoma naratyvine forma, potencialia „prasmès susikūrimo“ vieta, todèl jos interpretavimas leidžia tyrèjui atkurti paciento „pasakojimą“. Kai kuriais atvejais (pavyzdžiui, esant sunkioms autizmo formoms) piešinio kūrimo naratyvas ir jo analizè, Dubowskio įsitikinimu, dailès terapijoje yra svarbesni nei sukurto paveikslo interpetacija. Terapinis efektas pasiekiamas atkuriant minètą naratyvą ir taip sustiprinant dialogą tarp paciento sąmonès ir pasąmonès.

Jolita Rapolienè dailès terapiją vertina klinikinių reabilitacinių metodų kontekste ir jos poveiki tiria kompleksiškai, pabrèždama koreliacijas su ergoterapinèmis intervencijomis. Kaip ir kiti dailès terapijos metodų taikytojai, autorè remiasi tiesiogine fizinès ir emocinès būklès priklausomybe. Todèl, vertinant pacientus, patyrusius galvos smegenų insulta, ji reikalauja atsižvelgti ne tik i fizinę, bet ir emocinę būklę. Po insulto juos dažnai kamuoja nerimas ir depresi- ja, o tai kliudo sėkmingai reabilitacijai. Terapinès priemonès, inspiruojančios teigiamus emocinès būklès pokyčius, turi ittakos funkcinès būklès atstatymui ir šitaip didina reabilitacijos efektyvumą. Todèl greta iprastų metodu, dirbant su minèta pacientų grupe, autorè rekomenduoja papildomai taikyti dailès terapiją. Autorès pateikti kiekybinio tyrimo rezultatai rodo, kad reabilitacija, papildomai taikant dailès terapija, buvo efektyvi: tiriamuju fizinè būklè, jų savarankiškumas kasdienėje veikloje reikšmingai pagerèjo. Nerimo požymių turinčių pacientų skaičius reabilitacijos pabaigoje tiriamojoje grupejje statistiškai reikšmingai sumažèjo.

Vaida Adomaitienè pristato mišrų tyrima, analizuojanti dailès terapijos poveikį valgymo sutrikimų turinčių asmenų kūno savivokai. Tyrimas paremtas prielaida, kad a) valgymo sutrikimai inspiruoja neadekvačią kūno savivoka, o pastaroji grižtamuoju ryšiu palaiko valgymo sutrikimų dinamiką; b) dailès terapija gali būti naudinga koreguojant minètą savivoka, taip pat gydant kitus valgymo sutrikimu efektus. Autorès nuomone, diskutuodami apie savo kūna, klientai naudoja skurdžią žodžių atsargą arba tiesiog vengia šios temos. Vizualinè saviraiška dailès terapijos metu praplečia kliento komunikavimo galimybes ir padeda saugiai atverti jausmus, kurių raiškos klientas sąmoningai ar nesąmoningai vengia. Tyrimas neapsiribojo vien dailès terapijos efektyvumo izrodymais. Ne mažiau i̇domi, o gal net iddomesnè, yra jaunosios tyrëjos ambicija konkrečių valgymo sutrikimų simptomatiką sieti su ikonografinių elementų specifika. Paci- 
entụ pasirinktos ikonografijos analizé atskleide, jog specifiniai jos požymiai atliepia valgymo sutrikimų eigą ar pastebimus rizikos veiksnius, skatinančius sutrikimo formavimąsi. Giminingu iko- nografinių elementų kartojimasis skirtingų tiriamuju kūriniuose leidžia daryti prielaida, kad panaši sutrikimu simptomatika išreikšta panašiais ikonografiniais elementais.

\section{VIETOJ IŠVADŲ}

Dėstymo dalis pati savaime yra savotiška išvadų ir apibendrinimų grandinè. Todèl baigdami nužymèkime ne tik aptariamoje monografijoje keliama, bet ir netiesiogiai indikuojamą problematika, sietiną su dailès terapijos issitvirtinimo prielaidomis bei efektais.

- Bet kuri sritis susijusi su gretutiniais idejuc / mokslų laukais, ir šios sąsajos neišvengiamai verčia ją tarpdalykinių tyrimų objektu. Šiuo požiūriu dailès terapija, žinoma, nėra išimtis. Kita vertus, ši disciplina atspindi kitą tarpdalykiškumo aspekta, sietiną su kilme - neivveikiamą prigimtini dvilypuma, hibridišką humanitarinių ir medicinos mokslų jungti, paslèptą po terapinių tikslų vėliava.

- Dailès terapijos izsitvirtinimas atspindi medicinos mokslo galių išaugimą medicina subordinavo menines priemonès ir meninę logiką savo reikmėms. Meninės kūrybos kontekste išrasta vidujybės ir išorybès apykaita, tarp ju vykstantys komunikaciniai procesai suteikè medicinai galimybę atpažinti ir kontroliuoti vidujybès procesus kreipiant juos pageidaujama linkme.

- Taikomąji dailès terapijos pobūdi atitinka vakarietiškos meninès pastangos slinktis nuo abstrakčiu, ị universalijas orientuotuc vidujybès atverčių prie apibrèžtų, konkretų individą ar individu grupę kamuojančių problemų indikacijos / sprendimo. Arba tiesiog slinktis nuo universalijas atspindinčio meno prie taikomojo pobūdžio socialinio ar ideologinio angažuotumo.

- Tai ligos objektyvacijos problemos kèlimas ir jos sprendimo paieška. Dailès terapija nuolat ieško būdų, kaip bet kuriuos meninès kūrybos / tyrimo instrumentus subordinuoti medicinos poreikius atitinkančiai objektyvacijai: meninè saviraiška paverčiama vidujybės suišorinimo ekranu, o i ji nukreipti meninio tyrimo instrumentai - medicinai pritaikytomis priemonemis, indikuojančiomis vidujybejje paslèptą problemą/ligą.

- Dailès terapija atspindi reikšmingus pokyčius komunikacijos sampratu lauke; tai ne tik verbalinès komunikacijos sukeičiamumas su vizualine raiška, bet ir esminè pastarosios emancipacija, užtikrinanti kitaip nepasiekiamų individo vidinių turinių atverti. Ne mažiau svarbus kitas dailès terapijos indikuojamas pokytis psichinès ligos / sutrikimo turiniai iš prasminio niekio tapo i̇minimo reikalaujančia paslaptimi, raktu i universalią žmogišką vidujybę. 


\section{Literatūra ir nuorodos}

${ }^{1}$ Daugiau apie dailès terapijos disciplinos įtvirtinimą Lietuvoje žr. Audra Brazauskaitè, Aldona Dapkutè. Dailès terapija Lietuvoje šiandien, Daile kaip terapija. Sud. Dalley Tessa. Vilnius: Apostrofa, 2004, p. 234-242, ISBN 9955-605-02-2.

2 Pavieniai atvejai lygintini veikiau su išimtimi, nei taisykle.

${ }^{3}$ Prieš keletą dešimtmečių dailès terapija neturèjo aiškiai atpažistamos tapatybès nei Lietuvos visuomenèje, nei akademinèje medikų ar menininkų bendruomenëje, nebuvo savaime suprantama ir jos teikiama terapinè nauda. Nebuvo skiriamos dailès terapijos specialistu teikiamos paslaugos nuo atskiru dailès terapijos metodu taikymo, kuri siūlo kitų sričių specialistai, neturintys specifinių kompetenciju, ar tiesiog žmonès, savo žinias igiję lankant vienus ar kitus kursus. Nenuostabu, kad pradiniame etape kone visos veiklos, susijusios su dailès terapija, vykdè ne tik tiesiogines savo funkcijas, bet paraleliai siekè itvirtinti naujos profesijos atpažistamumą bei prestižă grindžiamą dailès terapijos efektyvumu pasirinktose srityse. Negalima sakyti, kad šiandien dailès terapija Lietuvoje nesusiduria su profesinès tapatybès iššūkiais, tačiau minètos problemos didele dalimi jau yra jau praeitis.

4 Pavyzdžiui, 1997 m. ìkurta Lietuvos dailes terapijos taikymo asociacija ir kt.

5 Žr. Liudmila Lebedeva, Dailes terapija: teorija ir praktika. Kaunas: Žmogaus psichologijos studija, 2013, ISBN 978-9955-9987-5-4 ir kt.

${ }^{6}$ Žr. Aldona Dapkutè, Kalba be žodžių: dailès kaip terapijos taikymo praktika. Vilnius: Rafaelis, 2003, ISBN 9955-9561-1-9; Laima Kriukelienè, Dailés terapija: mokomoji knyga. Kaunas: Vitae litera, 2009, ISBN 978-9955-920-72-4 ir kt.

7 Turbūt ankstyviausias ir ryškiausias pavyzdys bandant peržengti (nors iš esmès neperžengiant) minètą stereotipą yra: Daile kaip terapija. Sud. Dalley, Tessa. Vilnius: Apostrofa, 2004, ISBN 9955-605-02-2; gerokai vèlesnis pavyzdys: Modernaus meno socialiné reikšmé: meniniai - socialiniai performansai. Sud. A. Brazauskaitè, S. Dikčiūtè. Vilnius: Menų terapijos centras, 2015, p. 100-113, ISBN 978-609-95758-0-3. Plačiajai visuomenei mažiau žinoma, tačiau neabejotinai išskirtinio dèmesio nusipelniusi Kęstučio Šapokos disertacija „Dailès terapija kaip integrali sistema: kontekstuali analizè", apginta VDA $2008 \mathrm{~m}$. Joje demesys kreipiamas ne i taikomąsias, bet $\mathfrak{i}$ teorines pasaulèžiūrines dailès terapijos integralumo problemas, ju santykius su šiuolaikinèmis vizualinių menų konteksto idèjomis. Taip pat neabejotinai svarbus bandymas dailès terapijos prielaidas kildinti iš filosofinių ideju lauko. Žr. Vaida Asakavičiūtè, Apie filosofines dailès terapijos ištakas ir taikymo galimybes, Logos 88, 2016, I d., p. 65-72, ir Vaida Asakavičiūtè, Apie filosofines dailès terapijos ištakas ir taikymo galimybes, Logos 89, 2016, II d., p. 63-69.

${ }^{8}$ Menas, terapija, sveikata. Sud. S. Mostauskis, A. Brazauskaitè. Kaunas: VDA Kauno fakultetas, 2017, ISBN 978-9955-15-418-1.

${ }^{9}$ Būtina pažymèti, kad šio straipsnio autorius ir monografijos sudarytojas yra tas pats asmuo, todèl šis tekstas bent mokslinio objektyvumo požiūriu netapatintinas su kritine monografijos recenzija.

10 Straipsnyje siekiama pratęsti ir iš kitos perspektyvos papildyti V. Asakavičiūtès dèstomas idèjas, pakylejjant jas i labiau išgrynintus, bendresnio tipo teiginius. Žr. Vaida Asakavičiūtè, Apie filosofines dailès terapijos ištakas ir taikymo galimybes, Logos 88, 2016, I d., p. 65-72, ir Vaida Asakavičiūtè, Apie filosofines dailès terapijos ištakas ir taikymo galimybes, Logos 89, 2016, II d., p. 63-69.

11 Plačiau ši problematika aptariama kitame straipsnyje, žr.: Stanislovas Mostauskis, Akis į akį su gamtos demonais - psichoanalitinès pasaulěžiūros prielaidos, Psichoanalizés fenomeno interpretacijos. Sud. Antanas Andrijauskas, Vytautas Rubavičius. Vilnius: Meno rinkos agentūra, 2016, p. 91-104. ISBN 978-609-8014-18-1.

12 Tai tiesioginis skolinys iš angliakalbio konteksto, kuriam norètųsi rasti lietuvišką atitikmenį. Kita vertus, tik pati autore sprendžia, kurie vertiniai priskirtini tarptautinių žodžių kategorijai (naujame kontekste funkcionaliems skoliniams), o kurie pakeičiami lietuviu kalbos žodžiais. 